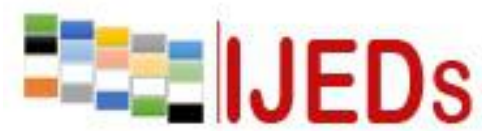

http://ijeds.ppj.unp.ac.id/index.php/IJEDS

\title{
THE EFFECT OF ROUND ROBIN TECHNIQUE AND ANXIETY TOWARD STUDENTS SPEAKING ACHIEVEMENT AT FORT DE KOCK NURSING ACADEMY
}

\author{
*Abizar Giffari \\ Language Education Program, Universitas Negeri Padang \\ Email : abizar_giffari07@yahoo.co.id \\ *Corresponding Author, Received: November 12, 2018, Revised: December 10, 2018, Accepted: December 21, 2018
}

\begin{abstract}
This study aims to explain the effect of Round Robin techniques and student anxiety on speaking ability. The design of this study was a quasi-experimental study with a factorial $2 \times 2$ design. The population of this study was first-level students at the Health Academy of Fort De Kock Bukittinggi. The ability to speak and the anxiety level questionnaire was used as a data collection tool for this study. Furthermore, the research data was by using the T-test formula and two-way ANOVA. The results showed that (1) groups of students with Round Robin techniques had better speaking skills than students with Memorization techniques, (2) groups of students with high anxiety with Round Robin technique has better speaking skills than Memorization techniques, (3) groups of students with low anxiety with Round Robin technique have good speaking skills from Memorization techniques and (4) there is no interaction between the two and anxiety towards students' speaking ability, where Fcount (0.0251) is lower than Ftable (4.96).
\end{abstract}

Keywords: Round Robin, Teaching Speaking,

\section{INTRODUCTION}

In order to be able to work in hospitals as offered in the domestic country, nurses must understand nursing science and practice, as well as they should be literate in English especially the spoken one in nursing field because hospitals in Indonesia has the tendency to become in international level. In 2012, Indonesia has 10 international hospitals that have been inaugurated by Indonesian government. In 2020, Ministry of Indonesia health has a plan to make an international hospital in everyprovince.

Sending health workers abroad became a trend topic in Indonesia. Especially for nurses, they are sent to America, Europe (Norwegian, Netherlands, England), 


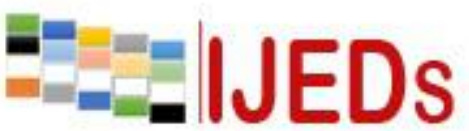

http://ijeds.ppj.unp.ac.id/index.php/IJEDS

Middle East (Egypt, UniEmirat, Kuwait), Singapore and Malaysia. Based on Development and Empowerment Human Resources Department data in 2013, there are 2494 nurses that are working abroad and $97.48 \%$ are nurses. Meanwhile, in recruitment of nurses that are sent abroad has a problem, one of requirements to be a nurse is mastering the English language. Lack of communication of Indonesian nurses to use English is one of the reasons why America, Europe and Middle East accept the nurses from other countries.

Because of the importance English subject in nursing for nursing academy, it is taught in three semesters, with two credits semester for each. Based on researcher's observations, interviews and diagnoses conducted to the nurse students, it isfound that there were several problems in teaching English speaking to nursing students of 2013 registered Fort De Kock Nursing Study Program. Based on result speaking test at previous semester. There were $75 \%$ of nurse still had low achievement in spoken English and 25\% students had high achievement. It means, There were 17 from 23 students who got $\mathrm{C}$ and $\mathrm{D}$ score. And 5 students got score $\mathrm{A}$ and $\mathrm{B}$. The students who got score $\mathrm{C}$ and $\mathrm{D}$ had to do remedial test.

The second problem is low motivation.in observation that was done on August 2014, The reseacher saw the students were having low motivation in speaking English, having lack of English spoken practice out of class, having low motivation in reading English text books, having lack of preparation before coming to the class, lack of motivation and students' language anxiety. All of internal factors mention above gave effect to the less participation of the nurse students to speak English during the class.

Next problems is from environment. One class consists of 35 until 45 students. It is difficult for the teacher to see student ability in speaking, the teacher has to see every student presentation. It will spend much time because, one student's presentationwill spend 5 until 10 minutes and if 35 students present their topic, it will spend 350 minutes. Another problem in class is when the students do presentation in front of class, almost all of their friends remember about what they will present and it will make the class noise.

In addition, the teacher uses conventional teaching. According to Arends (2004); Hermon and Dalim (2005); Hermon and Dalim (2006) there are three models of 


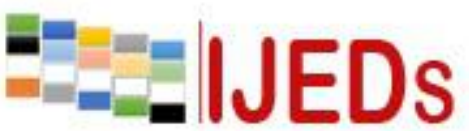

http://ijeds.ppj.unp.ac.id/index.php/IJEDS

conventional teaching technique; presentation, direct learning methods, and teaching learning by concept.Presentation includes the explanation from the teacher about the material, gives the questions, asks the questions, and evaluation. In class, the teacher uses presentation in every meeting. The teacher gives a topic to each group and the topic has to be presented in next meeting. It made students anxiety when studying English because they are afraid to make mistake in speaking. Especially in how to pronunciate and grammar.In observation, the reseracher interviewed the students. They felt anxiety when they were standing in front of class. It was caused by the fear of mistakes in grammar and pronunciation. Usually students that have low level and less confidence, they present in front of class by looking some text and usually focus on what they show in white board without looking the audience.

Students' anxiety in learning English is really bothering which affects students' learning achievement. If students' language anxiety gets higher, they cannot perform well in classroom. Most of students are nervous when it comes to speaking English or English test. Whenever they are in front of class, they tend to forget what they already have in mind. Their fear and nervousness in speaking, English test, and performing in class show that they already deal with anxiety since fear in speaking.

Based on the problem above, the reseacher used Round Robin technique to improve students speaking achievement. Teaching speaking by using Round-Robin Technique has advantages, Kagan (1994) says that the benefit of round robin strategy is students take turns suggesting answers or solutions to an open-ended problem. Furthemore, at several research about application of Round Robin Technique that was done by other reseachers, it prove which Round Robin Technique has positive effect in teaching speaking English language. It means that, Round Robin Techniquecan help to improve their speaking ability to convey ideas, giving advices or provide solutions based on topics that has been given.

\section{METHOD}

This research belongs to quasi-experimental research according to Gay, Mills and Airsian (2011) in quasi-experimental research, the researcher tests the hypothesis to find out cause and effect relationship. The researcher manipulated at least one 


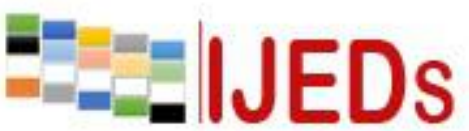

http://ijeds.ppj.unp.ac.id/index.php/IJEDS

\section{International Journal of Educational Dynamics}

Vol. 1 No. 1 (pp. 211-221) December 2018

p_ISSN 2655-4852

e ISSN 2655-5093

independent variable then controlled other variables and observed the effect of dependent variables. In this research, the researcher investigated the effect of independent variable. Round Robintechnique; the dependent variable namely speaking skill; and moderate variable is students' anxiety in speaking. The researcher used two groups namely experimental class and control class. Experimental class was taught by using Round Robintechnique and control class was taught by using Memorization technique. And this research was done in form of factorial design. Factorial designs are elaborative of single variable experimental designs to permit investigation of two or more variables, at least one of which is manipulated by the researcher (Gay, Mills, and Airasian, 2011). This research used $2 \mathrm{X} 2$ factorial design. It means that this research has two factors and each factor has two levels.

\section{RESULTS AND DISCUSSION}

Based on findings, speaking ability post test and the statistical analysis of hypothesis testing, it is concluded that there are some significant effects of teaching speaking by using Round Robin Technique to students' speaking ability by using Memorization Technique. In addition explanation about the result of the hypothesis testing are as follow.

\section{Hypothesis 1}

The result of first hypothesis shows that the value of $t$ observed is 5,1837 while the value of $\mathrm{t}$ table is 2,01537 with a $=0,05$. Since the value of $\mathrm{t}$ observed is bigger than $\mathrm{t}$ value. So, it can be said that Alternative Hypothesis (Ha) is accepted and Null Hypothesis (Ho) was rejected. It means that the students who were taught by Round Robin Technique have better students' speaking ability than those who were taught by Memorization Technique.

The result of first hypothesis is line with the theory prepared by Barkley (2014.67) he states that Round Robin Technique creates the opportunity for students to network and improve specific communication. Every student has opportunity to use their own words or sentences at speaking class. It can be seen when the students start to make a conversation. Every groups must collect many words or sentences that come 


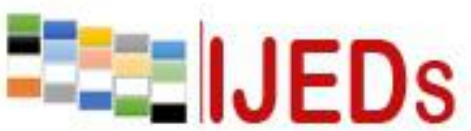

http://ijeds.ppj.unp.ac.id/index.php/IJEDS

from the students, after that, the students can make their own conversation based on the sentence that have been collected.

In addition, Hedge (2008) says that Round Robin Technique is one of the simplest tools you can use to keep everyone involved in a discussion, in Round Robin technique students have to make their own sentence based on the question or statement that has been given by teacher. So that, students has many choice sentences. The sentences can be from their friends sentences or the students can use their own sentence. Thus, it can help them in presentation.

According to Ferrer (2008) in round robin technique, each group member contirbutes an idea to the group in a systematic round-the-group fashion. It means that Round Robin Technique had given each student opportunities to use their their own word or sentence in group disscussion. So, when the students were speaking in front of class, they can remember word or sentence that would they say. In contrast, students in Control class did not take same part in learning speaking. In this technique, the students of course are divided into some groups, then they received a topic to be memorized. In fact, when they presented the conversation in front onf class. Some of students forget the text. As a result, students speaking ability in memorization technique was lower than students' speaking ability of Experimental Group. It is clear that, Round robin Technique gave better result on speaking ability than Memorization Technique.

\section{Hypothesis 2}

From the t-test calculation of second hypothesis, it is found that the anxiety students who are taught by using round robin technique have better speaking ability than those who are taught by using memorization technique. It can be seen from the value of $t$ observed is 3,067 while the value of $t$ table is 2,22814 with $a=0,05$. Since the value of $t$ observed is bigger than $t$ value. So, it can be said that Alternative Hypothesis (Ha) is accepted and Null Hypothesis (Ho) is rejected.

The second hypothesis, the students with high anxiety who are taught by Round Robin technique have better speaking ability than those were taught Memorization technique. It means, round robin technique that is used in experiment class can decrease students anxiety. Anxiety is one of thing that can influence students 


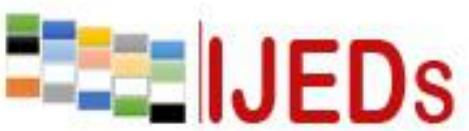

http://ijeds.ppj.unp.ac.id/index.php/IJEDS
International Journal of Educational Dynamics

Vol. 1 No. 1 (pp. 211-221) December 2018

p_ISSN 2655-4852

e ISSN 2655-5093

in speaking skill. Dornyei (2005) also sees the anxiety from the affective side, "anxiety is the quite possibly the affective factors that most pervasively obstructs the learning process. Anxiety is seeing as an affective factor for students in learning. By using Round robin technique, students that have high anxiety can use this technique. The finding in this research showed that teaching speaking by using the use of Round Robin techniquewas effectively enough to improve students speaking ability.It indicates that Round robin technique could improve students speaking skill in communicating their idea. Futhermore, the students also could overcome their anxiety to speak in front of class.

Meanwhile, related to the result of second hypothesis t-test calculation, the students with highanxiety taught by using Round robin Technique has better result in students speaking ability than those who were taught by Memorization Technique. The result of t-test and mean score indicated that Round RobinTechnqiue was better result on students' speaking ability. These differences were influenced by some factors. First, the students in experimental group who were taught by the Round robin Technique got more opportunity to create and share much ideas in their group. Each student could express their ideas, so it helped them to overcome their anxiety to their speaking ability. Second, this technique helped the students to be creative in their group. It is shown in their group activity, when the students got a topic that given by teacher, They have opportunity to make a conversation by their own sentence and it can make them easy to understand about the dialogue.

This was different from the control group. here, the students were given a dialogue. After the students memorized the dialogue, the students practiced it in front of class. Student that have low memorizing the dialogue had a problem in present the dialogue in front of class. Because the students felt worry or feeling uneasiness and anxiety. In fact, students who have low memorizing could not practice the dialogue well. explained by Scovel in Brown, 2007) states that anxiety is associated with feelings of uneasiness, frustration, self-doubt, apprehension, or worry. Nervousness, worry and tension always come when someone feeling anxiety. So, in this technqiue, not all students could participate the learning speaking activity. From the discussion above, it can be seen that the Round Robin Technique was the effective technique to students' 


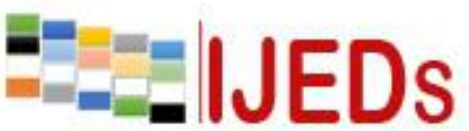

http://ijeds.ppj.unp.ac.id/index.php/IJEDS

\section{International Journal of Educational Dynamics}

Vol. 1 No. 1 (pp. 211-221) December 2018

p_ISSN 2655-4852

e ISSN 2655-5093

anxiety in teaching speaking. it can be proven by the mean score of students' speaking ability of high anxiety students.

\section{Hypothesis 3}

The result of t-test analysis of third hypothesis. The value of $t$ observed is 2,7161 while the value of $t$ table is 2,2814 with $a=0,05$. Since the value of $t_{\text {observed }}$ is bigger than $\mathrm{t}$ value. So, it can be said that Alternative Hypothesis (Ha) is acceptedand Null Hypothesis (Ho) is rejected. It means that The students with low anxiety who were taught by Round Robin Technique have better students' speaking ability than those who were taught by Memorization Technique.

The students in experimental group who were taught by the Round Robin Technique got more oppurtunity to create and share much ideas in their group. Each student could express their ideas, so it is helped them to have more sentences to their speaking ability. Second, this technique helped the students to be creative in their group. It is shown in their group activity, every students have to look for many answers or replay from the question that has been given by teacher. So, the students have many choices sentences when they do conversation.

Students who has low anxiety have good result, it is caused several factor,students that has low anxiety has small interferes, so that they can focus for what they speak. It line with Young (1999) says that anxiety often interferes students learning process. The interferes are feeling nervous, low confidence frustation and self-doubt. It is explained by Brown (2007) states that anxiety is associated with feeling of uneasiiness, frustation, self-doubt, apprehension or worry. Thus, student who has low anxiety has good result, becauser they can ignore a problem about anxiety.

Based on explanation above, it can be concluded that students were taught by round robin technique have better result than students who were taught conventional technique. And students who has low anxiety in experience class has good result that students who were taught by conventional technique. 


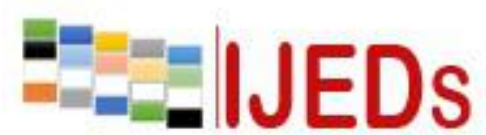

http://ijeds.ppj.unp.ac.id/index.php/IJEDS
International Journal of Educational Dynamics

Vol. 1 No. 1 (pp. 211-221) December 2018

p_ISSN 2655-4852

e_ISSN 2655-5093

\section{Hypothesis 4}

The result of fourth hypothesis shows that there is no interaction between teaching techniques and students anxiety on speaking ability. The statistical analysis shows that $F_{\text {observed }}$ is 0,0251 and $F_{\text {table is }} 4,96$. Null Hypothesis $\left(\mathrm{H}_{0}\right)$ is accepted and Alternative Hypothesis $\left(\mathrm{H}_{1}\right)$ is rejected. It means that there is no interaction between both treatment and students' anxiety in learning toward students' speaking ability.

Furthermore, the interaction graph between techniques and anxiety indicates that the lines are not cut one another. According to Irianto (2004), when there is an interaction between variables, the line of one factor toward dependent variable are cut one another. Based on this theory, it is concluded that the position of the lines shows there is no interaction between teaching techniques and students' anxiety on students' speaking ability. The speaking ability of students with high and low anxiety is assumed to have both weakness and profit, the first is about weakness, this can be seen where most of the students with high anxiety in both classes have a lower speaking ability compared with lower anxiety. It means those with low anxiety have better speaking ability.this is line with Young in Wang (2005) who noted that weakness anxiety is an increase in arousal or drive level which leads to a poor performance. From this statement, it is clear that stuidents' anxiety can decrease their performance so that they get a lower performance in this case their speaking ability. However, there are some students who have higher speaking ability eventhought they are categorized into high anxiety students. This is line with the theory proposed by Brown (2000) where benefit of helpful anxiety is that some concern or apprehension over a task to be accomplished is a positive factor. This is also supported by Casado (2001) that benefit anxiety is an increase in driven level which results in improved performance. According to those statements above, it is clear that the anxiety felt bythe students is a positive factor and it can be benefit for them in learning process so that their speaking ability can still be increased.

In summarizing, although the result of hypothesis testing shows that there is no interaction between teaching techniques and students' anxiety on students' speaking ability, the round robin technique brings significant result on students' speaking ability. So, it can be applied to all of students without considering their anxiety. Students' 


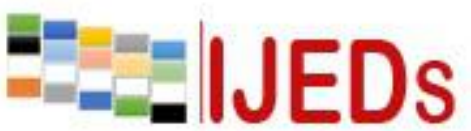

http://ijeds.ppj.unp.ac.id/index.php/IJEDS

\section{International Journal of Educational Dynamics}

Vol. 1 No. 1 (pp. 211-221) December 2018

p_ISSN 2655-4852

e ISSN 2655-5093

anxiety indirectly affect to students in order to make them become more active, but the interaction between teaching techniques and anxiety can not influence students' speaking ability.

\section{CONCLUSION}

The students who taught by using Round Robin Technique have better speaking ability than those taught by using Memorization Technique at students of STIKES Fort De Kock Nursing Academy. That is because this technique allows students to do interaction among them by doing interview so that their speaking ability can be trained and increased. The students with high anxiety taught by using Round Robin Technique do not have better speaking ability than those taught Memorization Technique. This is because they are afraid to take part in speaking anxiety and it may give effect on their speaking ability. The students with low anxiety taught by using Round Robin Technique have better speaking ability than those taught by using Memorization Technique. This is caused by Round Robin Technique allows and gives students more opportunities for them to practice their English. Especially their speaking. As seen in its procedures where the students are actively involved in each learning process. There is no interaction between both teaching technique and students' anxiety toward speaking ability. It is because the use of both teaching technique do not really give effect toward the students with high and low anxiety

\section{REFERENCES}

Arends, R.I. 2004. Learning to Teach. New York: McGraw-Hill

Barkley, E. F. M., C. Howell and C. K. Patricia. 2014. Collaborative Learning Technique: A Handbook for College Faculty. New York; John Wiley \& Sons

Brown, G and Y. George. 2000. Teaching the Spoken Language. Cambridge: Cambridge University Press

Brown, H. D and A. Priyanvada. 2007. Language Assessment: Principles and Classroom Practices. New York : Routledge.

Brown, H. D. 2007. Principles of Language Learning and Teaching. New York: Pearson Education.

Bucia, O. 2012. Sheltered Instruction Observation Protocol (SIOP) Strategy Guide for ELL/Bilingual Learner. Accessed from: http:/www.esd20.org/assets/1/6/ SIOP_Classroom_Stragtegies.pdf. November 2015. 
http://ijeds.ppj.unp.ac.id/index.php/IJEDS

Casado, M.A. 2001. Foreign Language Anxiety of University Students. College Student Journal, 35 (3).

Cronbach, L. J. 2002. Remaking the Concept of Aptitude: Extending the Legacy of Richard E. Snow. New Jersey : Lawrence Erlbaum Associates, Inc.

David, N. 2000. Second Language Teaching and Learning. Michigan: Heinle \& Heinle

Dornyei, Z. 2005. The Psychology of the Language Learner: Individual Differences in Second Language Acquisition. New York: Lawrence Erlbaum Associates.

Erianjoni and Jamalul Ihsan, 2017.Leading Public Transportation Drivers in Integrating Traffic Ethics Based on Nation Characters Value at Padang City. Journal of Education and Social Science. Volume 1 No. 1 (2017).

Ferrer, L. M. 2008. B.E.S.T. (Building Effective Strategies for Teaching) of Science. Manila: Book Store, Inc.

Fogg C, D. 1994. Team-Based Strategic Planning. New York, Amacom

Gay, L. R, Mills, Geoffrey and Airasian, Peter W. 2011. Educational Research: Competencies for Analysis and Applications. London: Pearson Education Inc

Hashempour, S. 2014. The Effect on Anxiety and Emotional Intelligence in Students' Leaarning Process. Vol. 1, Nop. 2; December. 2014

Hedge, T. 2008. Teaching and Learning in the Language Classroom. New York: Oxford University Press.

Hermon, D and Y. Dalim. 2005. Penggunaan Media Audio Visual untuk Meningkatkan Kreatifitas Belajar. Jurnal Pembelajaran. Vol. 28. Issue 3. p. 266-276

Hermon, D and Y. Dalim. 2006. Penerapan Kuliah Lapangan untuk Meningkatkan Hasil Belajar Mahasiswa. Forum Pendidikan. Vol. 28. Issue 3. p. 156-161

Horwitz, E. K., Horwitz, M, B., and Cope, J. 1990. Foreign Language Classroom Anxiety.inWilley Blackwell. Retrieved June 20, 2012, from http://www.jstor.org/stable/327317

Kagan, S. 1990. Kagan Cooperative Learning. San Clemente, CA: Kagan Publishing.

Kagan, S. 1994. Cooperative Learning. San Juan Capistrano, CA: Kagan Cooperative Learning

Leta, S. 2001. Depression Rates AmongCollage Students On The Rise. The Daily California. http://www.daiycal.org/article/6206/depression_rate_among_ college_students_on_the_ris

Lingualinks Library. 1999. Speaking Skill. Retrieved com. http://www.sil.org/lingualink. On January 9, 2007.

Liu, W. Chung. 2006. Memorization and Improvisation: a Comparison of Two Strategies in the Oral Acquisition of English as a School Language. Australia: Australia Catholic University.

Klippel, M. 1992. The Best Strategies for English Classroom. London. Pearson Education.

Nunan. D. 2000. Language Teaching Methodology: A Textbook for Teacher. London: Longman

Richards, J. C. 2002. Language Teaching and Applied Linguistics. London. Pearson Education

Serbessa, D. 2006. Tension Between Traditional and Modern Teaching Learning Approaches in Ethiopian Primary School. CICE Horishima University Journal of International Cooperation Education, Vol 9 No. 1 pp 123-144. 
International Journal of Educational Dynamics

$= \pm$ IJUEDS

Vol. 1 No. 1 (pp. 211-221) December 2018

p_ISSN 2655-4852

http://ijeds.ppj.unp.ac.id/index.php/IJEDS

e ISSN 2655-5093

Shumin, K. 1997. Factors to Consider: Developing Adult EFL Students' Speaking Abilities. Retrieved from Http://exchanges.state.gov/forum/vol35/index. htm.top. On December 15, 2006.

Young, D. 1991. Creating a Low-Anxiety Classroom Environment: What Does Language Anxiety Research?. The Modern Language Journal. 